\title{
Development Research:The Role of Supply Chain Management on Increasing the Company's Productivity
}

\author{
Hana Catur Wahyuni \\ Departemen Industri \\ Universitas Muhammadiyah Sidoarjo \\ Sidoarjo, Indonesia
}

\author{
Wiwik Sumarmi \\ Departemen Industri \\ Universitas Muhammadiyah Sidoarjo \\ Sidoarjo, Indonesia
}

\begin{abstract}
Productivity is a major indicator of company development. Various efforts are done by the company in order to improve the productivity of the company, one of which is the implementation of supply chain management. In its implementation, the management of supply chain management is implemented by the company as one of the strategies to improve the effectiveness and efficiency of the resources owned by the company in order to produce maximum output, according to the company target. This article aims to conduct a theoretical study related to the role of supply chain management on increasing productivity. The research method used in this study is a survey in the article indexed Scopus. Furthermore, the data is processed by using discrete statistics grouped by time of publication, and the subject area and mapping of the best practice role of supply chain management on increasing productivity based on the Scopus indexed article. The results showed that there were 1036 Scopus indexed articles in the 1979- 2017 (June) range. The role of productivity management in improving productivity is aped aspects: suppliers, reducing the disability that arises from the supply chain, the use of technology and some problems that often arise on the relationship between the supplier and the buyer.
\end{abstract}

Keyword-management; supply chain; productivity; literature review

\section{INTRODUCTION}

The rapid competition between industries, services or manufacturing requires every industry to undertake a variety of innovations to maintain the survival of its business. Concretely, business survival occurs if the company is able to maintain, even improve business productivity. Conclusively, productivity is defined as the relationship between output and input, producing output with limited resources, and high productivity is a key factor in maintaining long-term profitability $[1,2]$. In other contexts, productivity relates to effectiveness and efficiency resulting in decrease of cost per unit of product and positive impact to positive development on company investment in the future, for example in terms of labor, capital, raw material etc [3].
Therefore, in order to increase productivity, it is necessary to manage inputs efficiently in order to produce an effective output. One form into input management is through the implementation of supply chain management in business processes undertaken by the company. According [4], the supply chain consists of all parties directly or indirectly involved in meeting consumer demand, capable of describing the flow of information, money and goods and their transfers from suppliers to producers, distributors, retailers and ends in the consumer. In the context of productivity, coordination of management between various parties involved is expected to increase efficiency in the utilization of inputs into output.

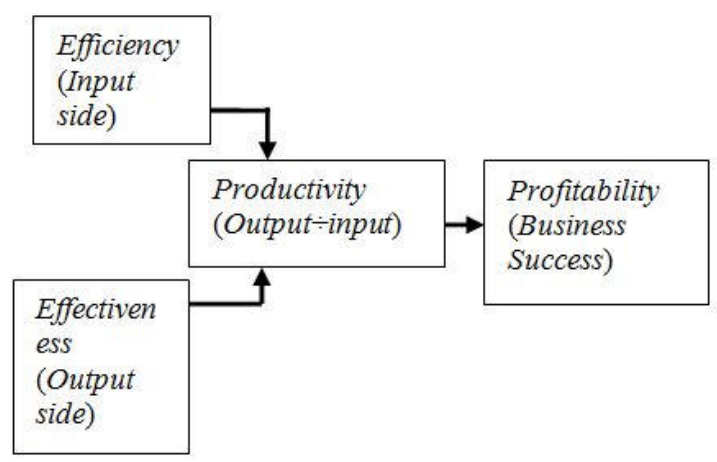

Fig. 1. The relationship between productivity with efficiency and effectiveness [3]

Supply chain management is a form of management between various parties of the company (suppliers, manufacturers, distributors, agents etc.). Supply chain management is a group of activities in the process of transforming goods and distribution of goods from raw materials to final consumers, with key players being supplies, manufactures, distributors, retail outlets, customers. On the other hand, supply chain management can be defined as the overall function of the organization of the company that deals with consumers, suppliers, manufacturers and distributors, especially in the flow of material, information and finance through several stages: plan, analyze, develop, integrate, deliver and return [5]. 
Coordination among the various stakeholders encourages the creation of quality products, more optimal cost and products acceptable to consumers on time. With increasing competition in global markets, companies are required to be able to integrate the various information contained in all company elements in a supply chain [6]. Moreover, the implementation of supply chain management in the company has a positive influence on operational capability, especially in increasing the value (value) owned by the company [7].

The problem that will be discussed in this paper is how the role of supply chain management in the process of improving the productivity of the company. While the objectives to be achieved through this paper are to provide an understanding of supply chain management practices that can encourage the increase in company productivity. Benefits obtained through this paper is the creation of an understanding related to the implementation of supply chain management in the process of improving the productivity of the company, so as to encourage the entrepreneurs to take strategic decisions on the company's operational processes related to the suppliers, manufacturers, distributors, retailers and consumers.

\section{METHOD}

The theoretical study of the role of supply chain management on improving corporate productivity is based on survey results of published scientific articles in various Scopus-indexed journals. The main data source is obtained from Scopus which is accessed with the keyword "supply chain management and productivity". The data obtained were processed with discrete statistics, grouped by time of publication, and research area (subject area). Furthermore, a mapping of best practice role of supply chain management will be done to increase productivity based on Scopus indexed articles

\section{FINDINGS}

Based on the results of the study through a survey with an article data source that scopus index until June 2017, it is known that there are 1036 articles in the keyword "supply chain management and productivity" published in the range of 1979 to 2017 (June). The development of the number of articles in the last 10 years is as follows:

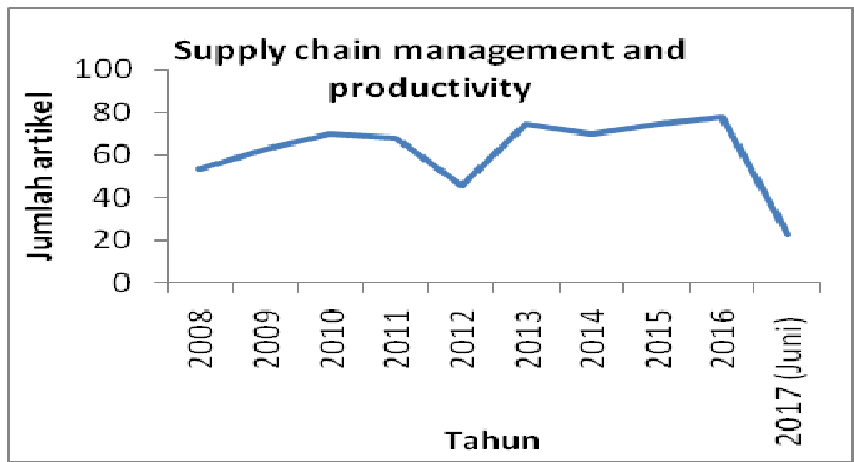

Fig. 2. The number of articles in the last 10 years
Figure 2 shows the data onto the number of Scopus indexed articles in "supply chain management and productivity" in the last 10 years. Based on the picture shows that there is a dynamic development changes, seen from the ups and downs of the number of articles per year. In the last 3 years, there has been an increase in the number of articles, which illustrate articles in this topic more interesting to study. Based on the scope of the discussion, 10 of the highest scopes that many discussed with the keyword "supply chain management and productivity" consist of: (1) engineering, (2) business, management and accounting, (3) computer science, (4) decisions sciences, (5) enviromental science, (6) agriculture and biologycal science, (7) social science, (8) chemical engineering, (9) material science, (10) energy.

The results show that supply chain management and productivity is much studied in terms of engineering (engineering). Some of the articles that deal with supply chain management and productivity in terms of engineering include the increase of sales, profit and productivity by using supply chain management [8], and the DEA fuzzy model as a means of evaluating supplier effectiveness and efficiency [9].

Based on the published article data onto Scopus, then the role of supply chain management on increasing productivity can be shown through several forms:

TABLE 1. ROLE OF SUPPLY CHAIN ON PRODUCTIVITY

\begin{tabular}{|c|c|c|}
\hline Author, year & Research purposes & Object \\
\hline [10] & $\begin{array}{l}\text { Determine supplier } \\
\text { indicators to improve } \\
\text { productivity }\end{array}$ & Milk \\
\hline [11] & $\begin{array}{l}\text { Fixed the defect rate } \\
\text { through the supply } \\
\text { chain model }\end{array}$ & $\begin{array}{l}\text { Foundry } \\
\text { industry }\end{array}$ \\
\hline [12] & $\begin{array}{l}\text { Know the use of } \\
\text { technology to increase } \\
\text { productivity in the } \\
\text { supply chain }\end{array}$ & Retail \\
\hline [13] & $\begin{array}{l}\text { Application of the } \\
\text { internet of things on } \\
\text { improving supply chain } \\
\text { management efficiency }\end{array}$ & Agriculture \\
\hline [14] & $\begin{array}{l}\text { Know the specific } \\
\text { problems that arise out } \\
\text { of the supplier-buyer } \\
\text { and affect the } \\
\text { productivity }\end{array}$ & $\begin{array}{l}\text { International } \\
\text { industry }\end{array}$ \\
\hline [15] & $\begin{array}{l}\text { Know the impact of } \\
\text { economic value on the } \\
\text { supply chain of fish }\end{array}$ & Fish \\
\hline [16] & $\begin{array}{l}\text { Know the factors that } \\
\text { affect and cost based } \\
\text { on the supply system }\end{array}$ & Forest chip \\
\hline [17] & $\begin{array}{l}\text { Exploring lean supply } \\
\text { chain capabilities to } \\
\text { improve environmental } \\
\text { performance }\end{array}$ & $\begin{array}{l}\text { Manufacturing } \\
\text { firm }\end{array}$ \\
\hline
\end{tabular}

The data onto table 1 shows some studies related to the role of supply chain management on increasing 
productivity. Several aspects of supply chain management related to increased productivity include suppliers, reducing defects arising out of the supply chain, technology utilization and some of the problems that often arise in the relationship between suppliers and buyers. Supplier is one of the actors in supply chain management for each product. In the context of productivity, suppliers are key to maintaining the sustainability of the production system, especially in terms of the quantity of supply and quality of the supplied materials. The non-conformity with the quantity and quality of materials supplied, will result in a hampering of the production process, and lead to unachievable targets.

Selection of the technology used in the supply chain, will affect the inaccuracy in the delivery process, in terms of time and quantity. In the supply chain, technology is used as a tool to streamline the flow of information about distributors and consumers. Technology will help every actor in the supply chain to give each other accurate information so that the goods. A good and clear relationship between suppliers and buyers in an effective and efficient supply chain management system will lead to increased productivity. Technology is able to improve the effectiveness and efficiency of the logistics system as a whole so as to encourage the growth performance and competitiveness of logistics systems in the supply chain [18].

Due to the existence of such, then consumer expectation will be fulfilled. Basically productivity depends on the consumer and also depends on the conditions of the supply chain structure [19] i.e.,supplier and customer relationships, cost reduction and waste elimination [20]. This condition will encourage the creation of a sense of satisfaction with consumers of services obtained from certain companies. Such satisfied feelings will encourage consumers to buy back on products of similar companies, thereby growing consumer loyalty.

\section{CONCLUSION}

The role of supply chain management is a topic of great interest in researchers. Based on data onto Scopus indexed publications, various studies of various aspects of supply chain management role in productivity have been studied by researchers. Recorded 1036 articles indexed Scopus with the keyword "supply chain management and productivity". The results show that supply chain management and productivity is a research topic that is still in demand by researchers, seen from the increase in the number of articles increased in the last 3 years. In terms of scope, engineering is the scope of the most widely published article in supply chain management and productivity. The results also show that the role of supply chain management on productivity improvement can be seen from several aspects, such as: suppliers, reducing the defects that arise out of the supply chain, the use of technology and some problems that often arise in the relationship between the supplier and the buyer.

\section{ACKNOWLEDGEMENTS}

Thanks to Universitas Muhammadiyah Sidoarjo for supporting this research.

\section{REFERENCES}

[1] Tangen S, 2002, "Understanding the concept of productivity", Proceedings of the 7th Asia Pacific Industrial Engineering and Management Systems Conference (APIEMS), Taipei.

[2] Shin S., Eksioglu B, 2015, "An empirical study of RFID productivity in the U.S. retail supply chain”, International Journal Production Economic, 163, pp 89-96.

[3] Phusavat K, 2013, "Productivity Management In An Organization, Measurement and Analysis", To Know Press, Bangkok.

[4] Chopra S., Meindl P, 2007, "Supply Chain Management: Strategy, planning and operation", Pearson-Ptentice Hall, New Jersey.

[5] Skukla., Garg D., Agarwal, 2011, "Understanding Of Supply Chain: A Literatur and Review", International Journal of Engineering Science and Technology (IJEST), Vol 3 No 3, pp 2062- 2072

[6] Lotfi Z., Sahran S., Mukhtar M., Zadeh A.T., 2013, "The Relationship Between Supply Chain Integration And Product Quality", Procedia Technology, 11, pp 471-478.

[7] Ai Chin T., Hamid A.B., Raslic A., Hock Heng L, 2014, "The Impact Of Supply Chain Integration On Operational Capability In Malaysian Manufacturers", Procedia Sosial and Behavioral Sciences 130, 257- 265.

[8] Javaid M., Garg D., Ali A, 2012, Increasing sale, profit rate and productivity improvement using supply chain management: A case study, International Journal of Applied Research, Vol 7 Iss 11, pp 1351-1357.

[9] Azadi M., Jafarian M., Saen R.F., Mirhedayatian S.M, 2015, “A new fuzzy DEA model for evaluation of efficiency and effectiveness of suppliers in sustainable supply chain management context", Computer and Operation Research, Vol 54, February, pp 274-285.

[10] Okano M.,T, Vendrametto O., Santos O.,S.,D, 2010, "Organizing the dairy chain through productivity indicators for a sustainable supply chain", International Conference on Chemistry and Chemical Engineering, Proceedings, Kyoto- Jepang, pp 258-260

[11] Nallusamy S, Umarmukdhar M.,A.,M, Rekha S.,R, 2016, "A Purposed Supply Chain Model For Productivity Enhancement In Medium Scale Foundry Industries", International Journal of Engineering In Africa, Vol 20, pp 248-258.

[12] Bopape J, Campbell H.,M, Munyai T, 2016, "The Impact Of Technology In Improving Productivity And Cost Serve In Supply Chain: Case Study-Woolworths", 25th International Association for Management of Technology Conference, Proceedings: Technology - Future, Orlando, US, pp 1421-1427.

[13] Wang X, Liu N, 2014, "The Application Of Internet Of Things In Agrycultural Means Of Production Supply Chain Management", Journal Of Chemical And Pharmaceutical Research, Vol 6 Iss 7, pp 2304-2310.

[14] Allmayer S., Winkler H, 2014, Supply Chain Interface Problem Affecting Productivity, International Journal of Logistic System And Management, Vol 18, Iss 4, pp 415-435.

[15] Kankainen M., Setala J., Kause A., Quinton C., Airaksinen S., Koskela J, 2016, Economic values of supply chain productivity and quality traits calculated for a farmed European whitefish breeding program, Aquaculture Economic and Management, Vol 20, Iss 2, pp 131- 164.

[16] Eliasson L., Eriksson A., Mohtashami S., 2017, Analysis of factors affecting productivity and costs for a high-performance chip supply system, Applied System, Vol 185, pp 497- 505.

[17] Parveen, C.M., Kumar, A.R.P., Narasimha Rao, T.V.V.L, 2011, Proceedings of the International Conference on Green Technology and Environmental Conservation, GTEC, pp 143-147.

[18] Bandhari R, Impact Of Technology On Logistics And Supply Chain Management, IOSR Journal of Business and Management (IOSRJBM), pp 19-24.

[19] Serpa C.,J, Krishnan H, 2017, The Impacs Of Supply Chains On Firm-Level Productivity, Management Science, Maret. Published online: doi.org/10.1287/mnsc.2016.2632 
[20] Al- Tit A, 2016, The Impact On Lean Supply Chain On Productivity Of Saudi Manufacturing Firms In Al- Qassim Region, Poliash Journal Of Management Studies, Vol 14, No 1, pp 18- 27. 